\title{
Ainhum or Dactylolysis Spontanea: a Missing Toe
}

\section{Ainhum ou Dactilólise Espontânea: Dedo do Pé Desaparecido}

Isabel SOUSA ${ }^{1}{ }^{1}$, António FERNANDES ${ }^{1}$, Isabel TÁVORA ${ }^{1}$

Acta Med Port 2016 Jan;29(1):79-79

Keywords: Ainhum; Toes.

Palavras-chave: Ainhum; Dedos do Pé.

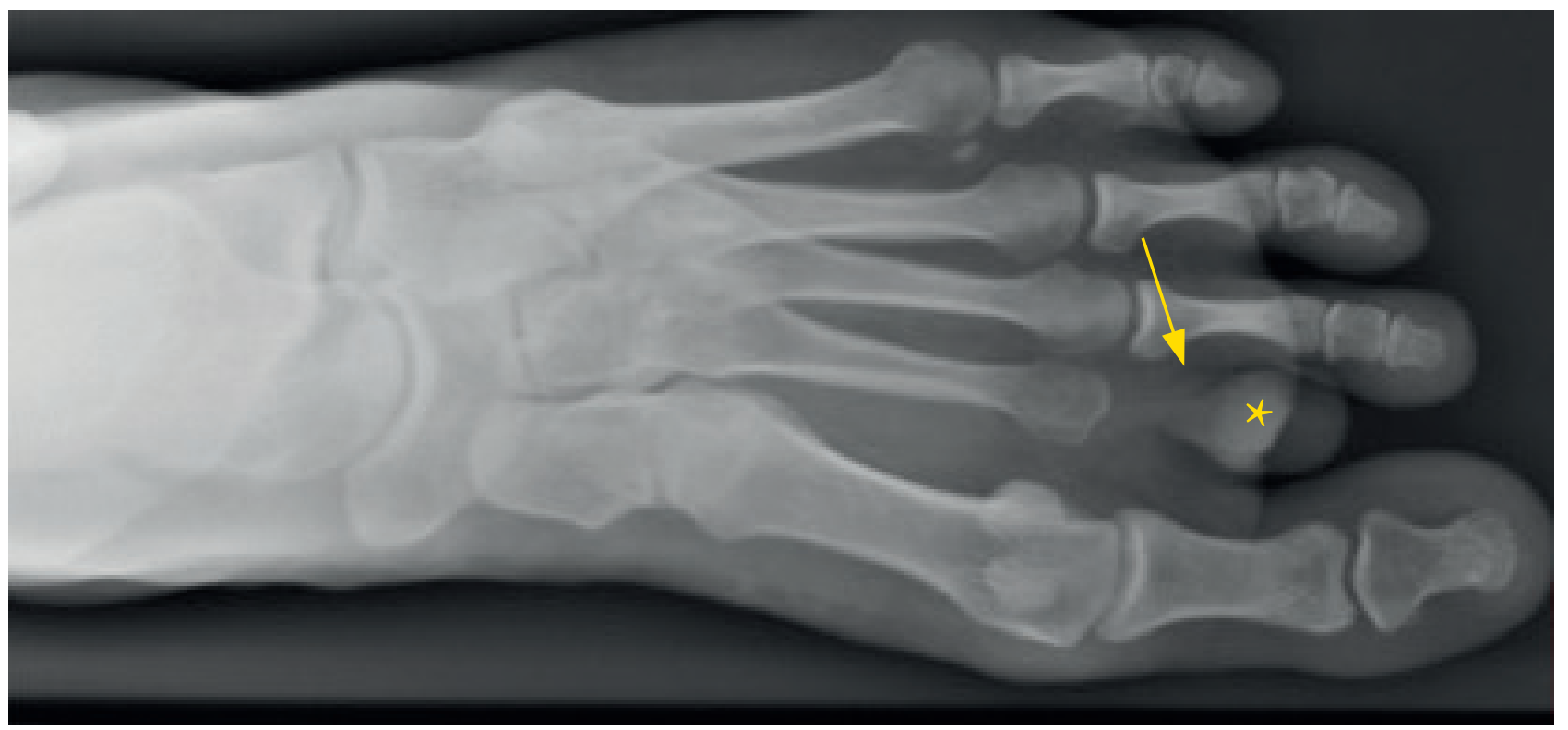

Figure 1 - Radiograph of the left foot in dorsal-plantar view

We present the case of a 36-year-old black male immigrant born in the Amazon (Brazil) who had an unstudied deformity of the second left toe since childhood. A radiograph of the foot was performed, revealing absence of the phalanges of the second toe (star in Fig. 1) with an intact corresponding metatarsal bone and a stricture of the soft tissues at the base of the toe (arrow in Fig. 1). These findings suggested the diagnosis of ainhum, also called dactylolysis spontanea. This condition of unknown aetiology occurs in the tropical and subtropical regions, usually affects black individuals ${ }^{1}$ and manifests more frequently in the fifth toe, although it can involve other toes, ${ }^{2}$ as in our case. It results from the development of a fibrotic band encircling the proximal end of the toe, leading to bone reabsorption of the phalanges followed by autoamputation. The treatment can include anti-inflammatory drugs or surgery, depending on the stage of the disease.

\section{REFERENCES}

1. Carvalho N, Silveira J, Rodrigues L, Tirado A, Ferreira M. Ainhum (dactylolysis spontanea): a case report. Foot Ankle Surg. $2000 ; 6: 189-92$.

2. Daccarett M, Espinosa G, Rahimi F, Eckerman CM, Wayne-Bruton S, Couture M, et al. Ainhum (dactylolysis spontanea): a radiological survey of 6000 patients. J Foot Ankle Surg. 2002;41:372-8.

\footnotetext{
1. Serviço de Imagiologia Geral. Hospital de Santa Maria. Centro Hospitalar Lisboa Norte. Lisboa. Portugal.

$\triangle$ Autor correspondente: Isabel Sousa. isabelrsousa@gmail.com

Recebido: 04 de maio de 2015 - Aceite: 10 de agosto de 2015 | Copyright @ Ordem dos Médicos 2016
} 